\title{
Pulse-Impact on Microstructure of Liquid-Phase-Pulse-Impact Diffusion Welded Joints of Particle Reinforcement Aluminum Matrix Composites at Various Temperatures
}

\author{
Kelvii Wei Guo \\ Department of Mechanical and Biomedical Engineering, City University of Hong Kong, Hong Kong, China \\ Email: kelviiguo@yahoo.com
}

Received February 28, 2011; revised January 1, 2013; accepted January 8, 2013

Copyright (C) 2013 Kelvii Wei Guo. This is an open access article distributed under the Creative Commons Attribution License, which permits unrestricted use, distribution, and reproduction in any medium, provided the original work is properly cited.

\begin{abstract}
Investigation was to study the influence of pulse-impact on microstructure of Liquid-Phase-Pulse-Impact Diffusion Welding (LPPIDW) welded joints of aluminum matrix composite $\mathrm{SiC}_{\mathrm{p}} / \mathrm{A} 356, \mathrm{SiC}_{\mathrm{p}} / 6061 \mathrm{Al}, \mathrm{Al}_{2} \mathrm{O}_{3 \mathrm{p}} / 6061 \mathrm{Al}$. Results showed that under the effect of pulse-impact: 1) the interface state between reinforcement particle $\left(\mathrm{SiC}_{2} \mathrm{Al}_{2} \mathrm{O}_{3}\right)$ and matrix was prominently; 2) the initial pernicious contact-state of reinforcement particles was changed from reinforcement $\left(\mathrm{SiC}, \mathrm{Al}_{2} \mathrm{O}_{3}\right)$ /reinforcement $\left(\mathrm{SiC}, \mathrm{Al}_{2} \mathrm{O}_{3}\right)$ to reinforcement $\left(\mathrm{SiC}, \mathrm{Al}_{2} \mathrm{O}_{3}\right) /$ matrix/ reinforcement $\left.\left(\mathrm{SiC}_{2} \mathrm{Al}_{2} \mathrm{O}_{3}\right) ; 3\right)$ the density of dislocation in the matrix neighboring to and away from the interface in the matrix was higher than its parent composite; and 4) the intensively mutual entwisting of dislocation was occurred. Studies illustrated that: 1) deformation was mainly occurred in the matrix grain; and 2) under the effect of pulse-impact, the matrices around reinforcement $\left(\mathrm{SiC}, \mathrm{Al}_{2} \mathrm{O}_{3}\right.$ ) particles engendered intensive aberration offered a high density nucleus area for matrix crystal, which was in favor of forming nano-grains and improved the properties of the successfully welded composite joints.
\end{abstract}

Keywords: Aluminum Matrix Composite; Particle Reinforcement; Pulse-Impact; Microstructure; Diffusion Welding

\section{Introduction}

The high specific strength, good wear-ability and corrosion resistance of Aluminum Matrix Composites (AMCs) attract substantial industrial applications. Typically, AMCs are currently used widely in automobile and aerospace industries, structural components, and heat resistant-wearable parts in engines, etc. [1-5]. The particles of reinforcement elements in AMCs may be either in form of particulates or as short fibers, whiskers and so forth $[5,6]$. These discontinuous natures create several problems to their joining techniques for acquiring their high strength and good quality weld-joints. Typical quality problems of those welding techniques currently available for joining AMCs [7-15] are as elaborated below.

1) The distribution of particulate reinforcements in the weld

As properties of welded joints are usually influenced directly by the distribution of particulate reinforcements in the weld, their uniform distribution in the weld is likely to give tensile strength higher than $70 \%-80 \%$ of the parent AMCs. Conglomeration distribution or absence (viz. no-reinforcements-zone) of the particulate reinforcements in the weld generally degrades markedly the joint properties and subsequently resulted in the failure of welding.

2) The interface between the particulate reinforcements and aluminum matrix

High welding temperature in the fusion welding methods (typically: TIG, laser welding, electron beam etc.) is likely to yield pernicious $\mathrm{Al}_{4} \mathrm{C}_{3}$ phase in the interface. Long welding time (e.g. several days in certain occasions) in the solid-state welding methods (such as diffusion welding) normally leads to a) low efficiency and b) formation of harmful and brittle intermetallic compounds in the interface.

To alleviate these problems incurred by the available welding processes for welding AMCs, a liquid-phasepulse-impact diffusion welding (LPPIDW) technique has been developed [16-18]. This paper aims at providing 
some specifically studies the influence of pulse-impact on the microstructures of welded joints. Analysis by means of scanning electron microscope (SEM), transmission electron microscope (TEM) and X-Ray Diffraction (XRD) allows the micro-viewpoint of the effect of pulse-impact on LPPIDW to be explored in more detail.

\section{Experimental Material and Process}

\subsection{Specimens}

Stir-cast $\mathrm{SiC}_{\mathrm{p}} / \mathrm{A} 356, \mathrm{P} / \mathrm{M} \quad \mathrm{SiC}_{\mathrm{p}} / 6061 \mathrm{Al}$ and $\mathrm{Al}_{2} \mathrm{O}_{3 \mathrm{p}} /$ $6061 \mathrm{Al}$ aluminum matrix composite, reinforced with $20 \%, 15 \%$ volume fraction $\mathrm{SiC}, \mathrm{Al}_{2} \mathrm{O}_{3}$ particulate of 12 $\mu \mathrm{m}, 5 \mu \mathrm{m}$ mean size, were illustrated in Figures 1-3.

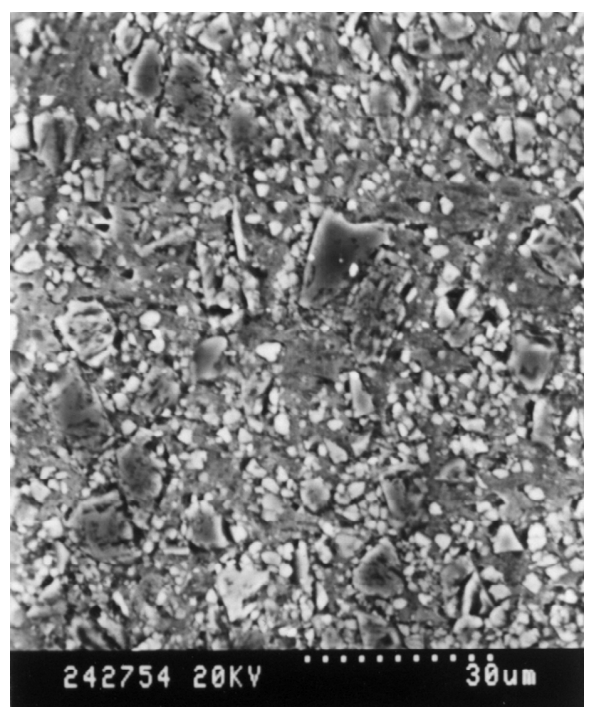

Figure 1. Microstructure of aluminum matrix composite $\mathrm{SiC}_{\mathrm{p}} / \mathrm{A} 356$.

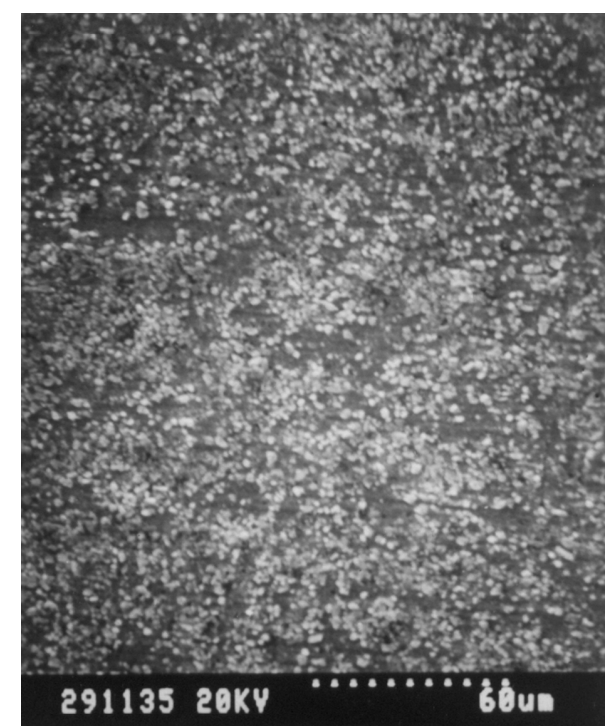

Figure 2. Microstructure of aluminum matrix composite $\mathrm{SiC}_{\mathrm{p}} / 6061 \mathrm{Al}$.

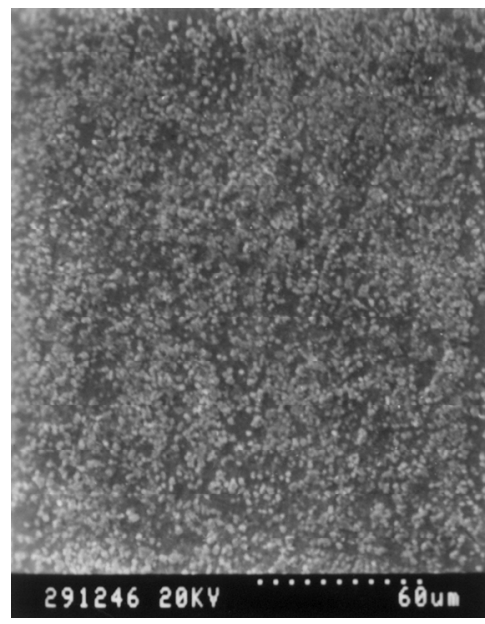

Figure 3. Microstructure of aluminum matrix composite $\mathrm{Al}_{2} \mathrm{O}_{3 \mathrm{p}} / 6061 \mathrm{Al}$.

\subsection{Experiment}

The quench-hardened layer and oxides, as induced by wire-cut process, on the surfaces of aluminum matrix composite specimens were removed by careful polishing using 400 \# grinding paper. The polished specimens were then properly cleaned by acetone and pure ethyl alcohol so as to remove any contaminants off its surfaces. A DSI Gleeble ${ }^{\circledR}-1500 \mathrm{D}$ thermal/mechanical simulator with a 4 $\times 10^{-1} \mathrm{~Pa}$ vacuum chamber was subsequently used to perform the welding.

The microstructures and the interface between the reinforcement particle and the matrix of the welded joints were analyzed by SEM and TEM.

\subsection{Operation of LPPIDW}

Figure 4 illustrated a typical temperature and welding time cycle of a LPPIDW. It basically involved with: 1) an initially rapid increase of weld specimens, within a time of $t_{a}$, to an optimal temperature $T_{a}$ at which heat was preserved constantly at $T_{a}$ for a period of $\left.\left(t_{b}-t_{a}\right), 2\right)$ at time $t_{c}$, a quick application of pulse impact to compress the welding specimens so as to accomplish an anticipated deformation $\delta$ within a glimpse of $10^{-4}-10^{-2} \mathrm{~s}$, whilst the heat preservation was still maintained at the operational temperature $T_{a}$; and 3 ) a period of natural cooling to room temperature after time $t_{b}$.

\section{Results and Discussion}

\subsection{Microstructure of Welded Joint}

Figure 5 showed the microstructures of welded joints of $\mathrm{SiC}_{\mathrm{p}} / \mathrm{A} 356$ at various temperatures with $V_{I}=560 \mathrm{~mm} / \mathrm{s}, t_{I}$ $=10^{-4}-10^{-2} \mathrm{~s}, t=30 \mathrm{~s}, P_{0}=5 \mathrm{MPa}, \delta=1 \mathrm{~mm}$, where $V_{I}$ was velocity of pulse-impact, $t_{I}$ was the impacting time, $t$ was holding time for heat preservation, $P_{0}$ was holding 


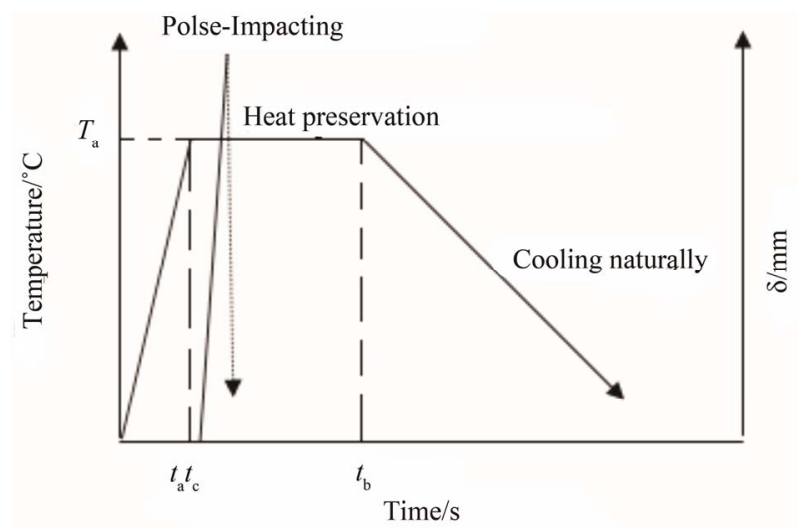

Figure 4. Schematic diagram of liquid-phase-pulse-impact diffusion welding.

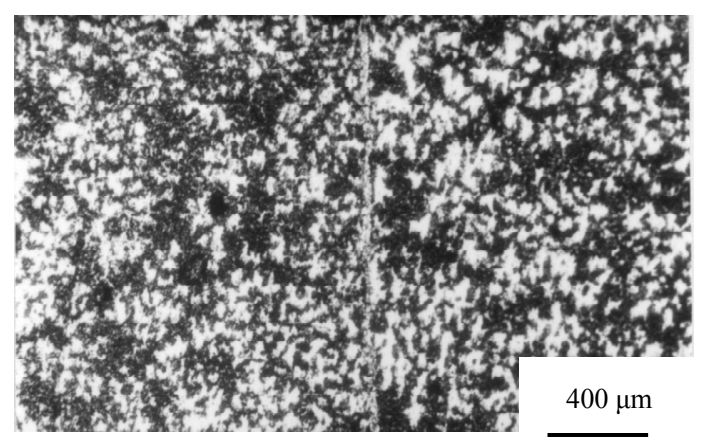

(a)

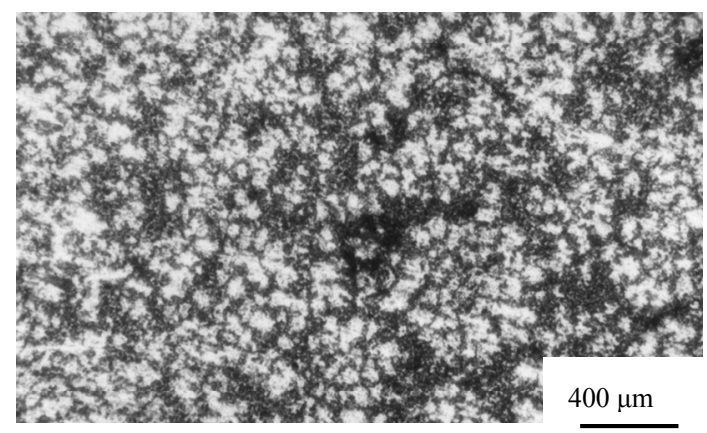

(b)

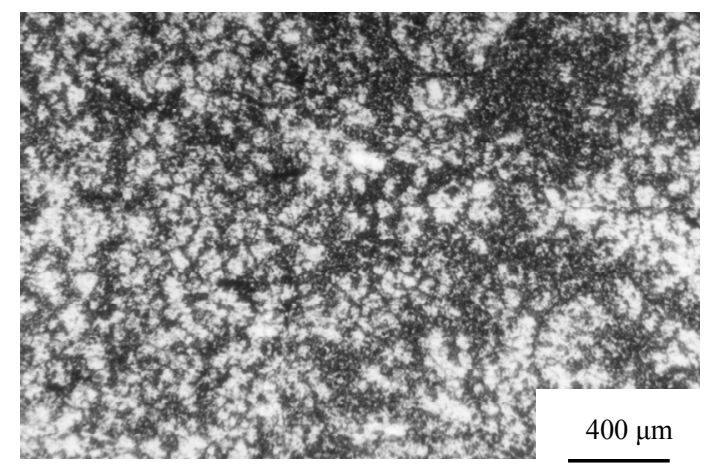

(c)

Figure 5. Microstructures of welded joints of $\mathrm{SiC}_{\mathrm{p}} / \mathrm{A} 356$ at various temperatures by LPPIDW; (a) $563^{\circ} \mathrm{C}$; (b) $565^{\circ} \mathrm{C}$; (c) $570^{\circ} \mathrm{C}$. pressure during the welding, $\delta$ was the horizontal deformation. It elucidated that when the welding temperature was $563^{\circ} \mathrm{C}$, under the effect of pulse-impact, the liquid phase matrix alloy wasn't formed enough to wet the particle reinforcements. In addition, at this temperature, the diffusion capability of the atoms within the matrix was relatively low. As a result, the welding interface between two specimens could be observed obviously as shown in Figure 5(a) and followed by the unsuitable strength (about $118 \mathrm{MPa}$ ). Moreover, because of lower welding temperature, the area of the formed solid-liquid phase was smaller, which led to some streamlines scattered in the matrix (Figure 5(a)) after the pulse-impact acting on the substrates. When the temperature reached $565^{\circ} \mathrm{C}$, the rate of the atom diffusion in the joint region within the matrix was accelerated (Figure 5(b)). At the same time, more liquid phase matrix alloy was formed to wet reinforcements $(\mathrm{SiC})$. Therefore, the interface state of reinforcement and reinforcement was improved and the reinforcements were distributed uniformly to some extent. Also, the streamlines scattered in the matrix were disappeared, and the tensile strength of welded joints was about $134 \mathrm{MPa}$ higher than that of $563^{\circ} \mathrm{C}$. When the temperature is up to $570^{\circ} \mathrm{C}$, the formed liquid phase matrix alloy was enough and suitable for wetting reinforcements effectively, and the rate of the atom diffusion was more active. As a result, for reinforcements the welding mode in the joint region changed from reinforcementreinforcement to reinforcement-matrix-reinforcement. Con- sequently, the joint was welded successfully (Figure 5(c)). The average strength of $179 \mathrm{MPa}$ for the welded joints produced at welding temperature of $570^{\circ} \mathrm{C}$ was about $74.6 \%$ of the $240 \mathrm{MPa}$ for the strength of parent aluminum matrix composite.

The relevant fractographs were shown in Figure 6. It illustrated that when the welding temperature was $563^{\circ} \mathrm{C}$, the initial morphology of substrate could be detected obviously, and some sporadic welded locations appeared together with some rather densely scattering bare reinforcement particles as shown in Figure 6(a). With the welding temperature was increased to $565^{\circ} \mathrm{C}$, more liquid phase was formed. Under the effect of pulse-impact, some wet locations in the joint had been excellently welded and the aggregated solid reinforcement particles were improved. However, the bare reinforcement particles were still distributed on the fractographic surface. It indicated that substrates did not weld ideally the pieces together and it consequently resulted in a low strength joint (Figure 6(b)). Figure 6(c) showed the fractograph of welded joint at $570^{\circ} \mathrm{C}$. It illustrated that the fracture was dimple fracture. Moreover, SEM of the fracture surface showed some reinforcement particles $(\mathrm{SiC})$ in the dimple. In order to confirm the state of these reinforcement particles, particles itself and matrix neighboring to 


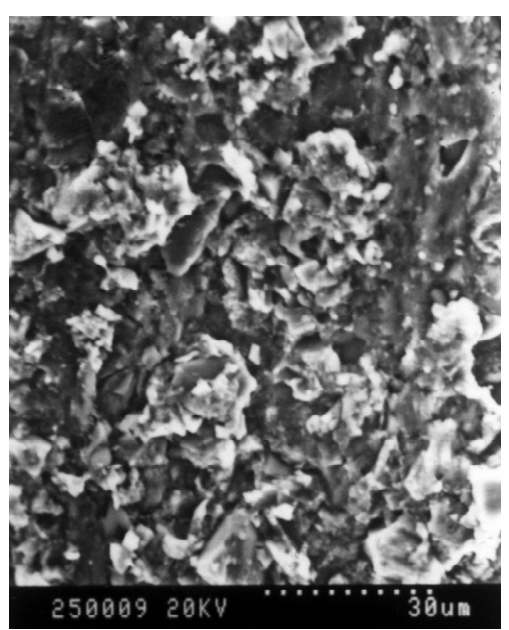

(a)

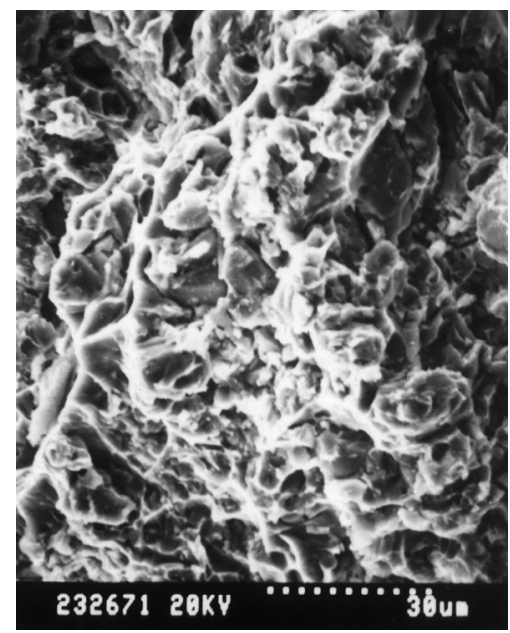

(c)

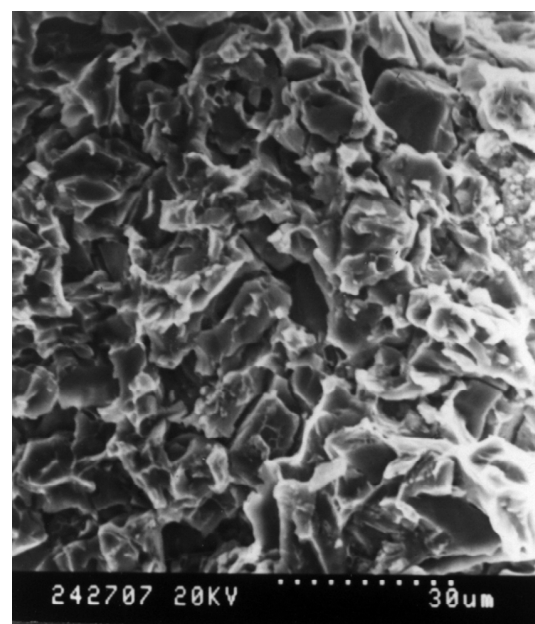

(b)

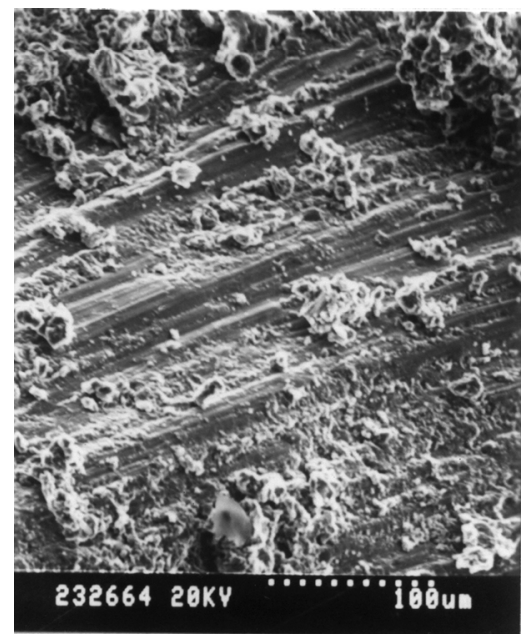

(d)

Figure 6. Fractographs of $\mathrm{SiC}_{\mathrm{p}} / \mathrm{A} 356$ at various temperatures; (a) $563^{\circ} \mathrm{C}$; (b) $565^{\circ} \mathrm{C}$; (c) $570^{\circ} \mathrm{C}$; (d) $575^{\circ} \mathrm{C}$.

these particles were analyzed by energy dispersive X-ray analysis (EDX) respectively. Result was shown in Figure 7. It indicated that reinforcement particles $(\mathrm{SiC})$ were wet by matrix alloy successfully suggesting that the reinforcement particles had been perfectly wet and the composite structure of reinforcement/reinforcement had been changed to the state of reinforcement/matrix/reinforcement.

As welding temperature increasing to $575^{\circ} \mathrm{C}$, it led to more and more liquid phase matrix alloy distributing in the welded interface, meanwhile, more liquid phase matrix alloy reduced the effect of impact on the interface of the welded joints, subsequently the application of transient pulse-impacting would cause the relative sliding of the weldpieces that jeopardized ultimately the formation of proper joint as shown in Figure 6(d). It demonstrated that results of fractographs were agreed with the corresponding microstructures well.

The relevant results of $\mathrm{SiC}_{\mathrm{p}} / 6061 \mathrm{Al}$ and $\mathrm{Al}_{2} \mathrm{O}_{3 \mathrm{p}} /$

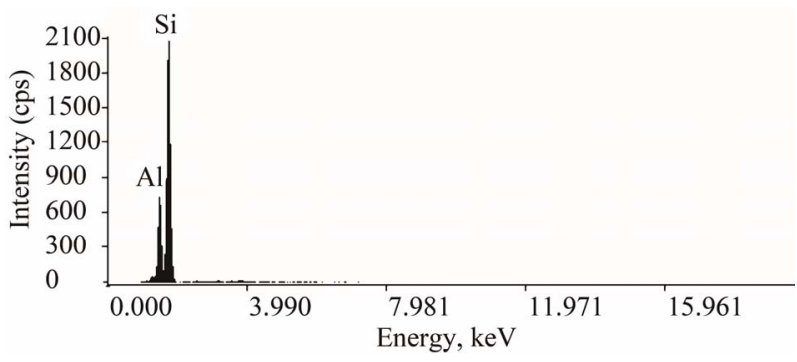

Figure 7. Energy dispersive X-ray analysis of the fracture surface of $\mathrm{SiC}_{\mathrm{p}} / \mathrm{A} 356$.

$6061 \mathrm{Al}$ at various welding temperatures were shown in Figures 8-11.

It showed that the microstructure evolutions and its corresponding fracture surfaces under the effect of pulseimpact are similar to that of $\mathrm{SiC}_{\mathrm{p}} / \mathrm{A} 356$.

Figures 8(a) and 10(a) showed when the welding temperature was too low to form enough liquid phase matrix 


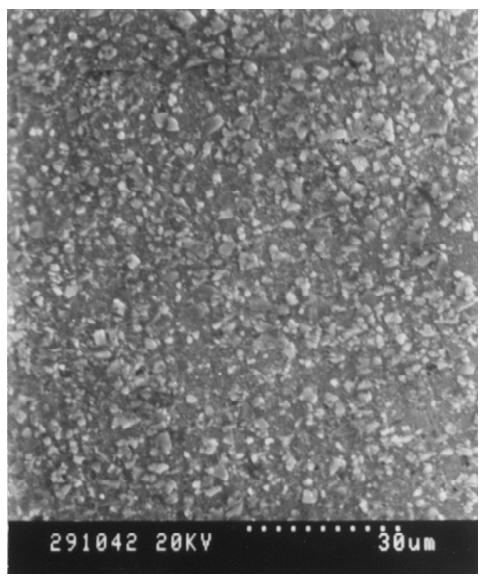

(a)

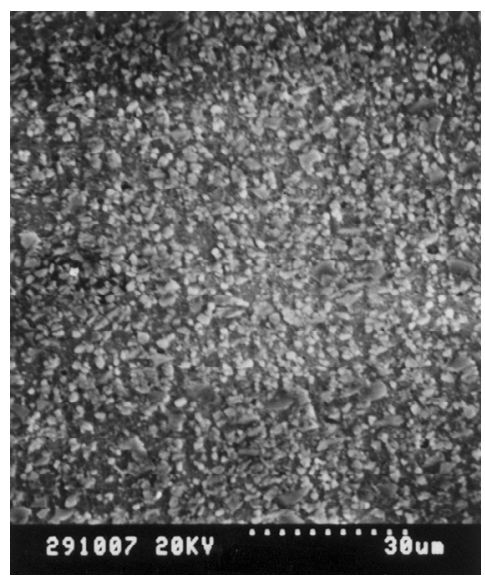

(b)

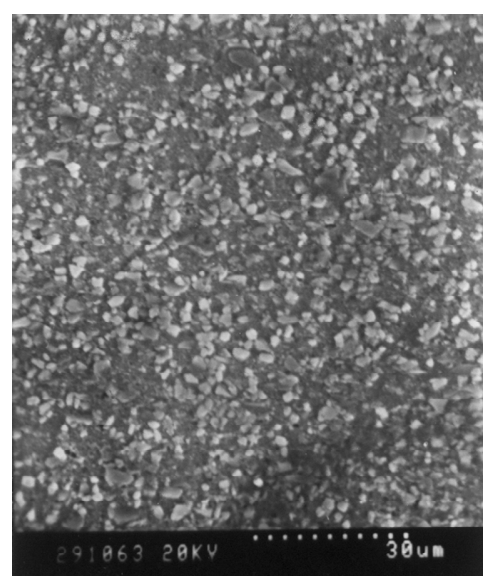

(c)

Figure 8. SEM micrographs of $\mathrm{SiC}_{\mathrm{p}} / 6061 \mathrm{Al}$ welded joints at various welding temperatures; (a) $620^{\circ} \mathrm{C}$; (b) $623^{\circ} \mathrm{C}$; (c) $625^{\circ} \mathrm{C}$.

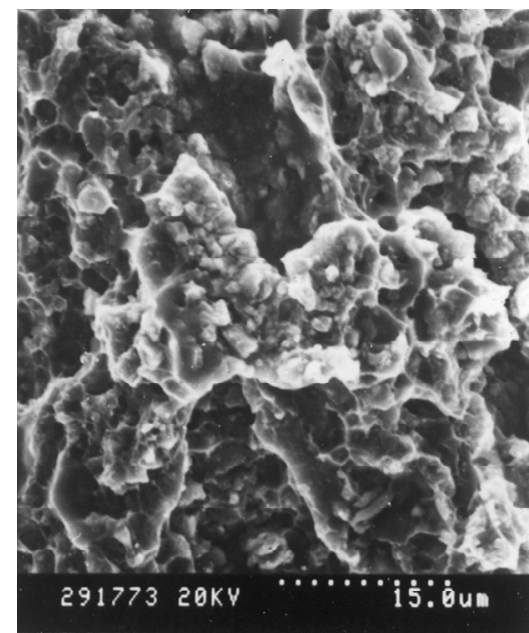

(a)

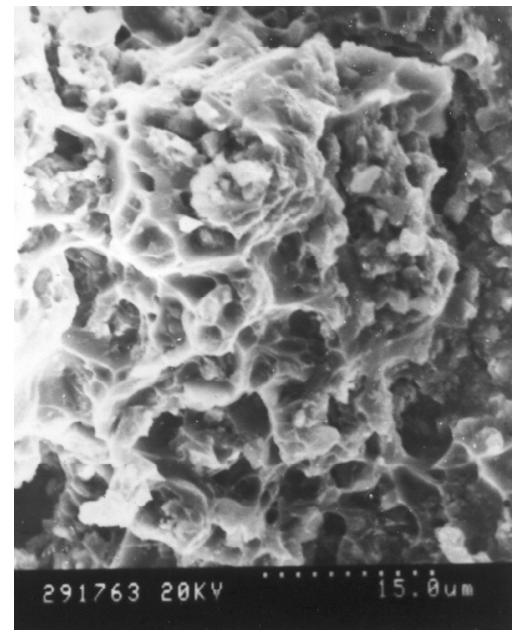

(b)

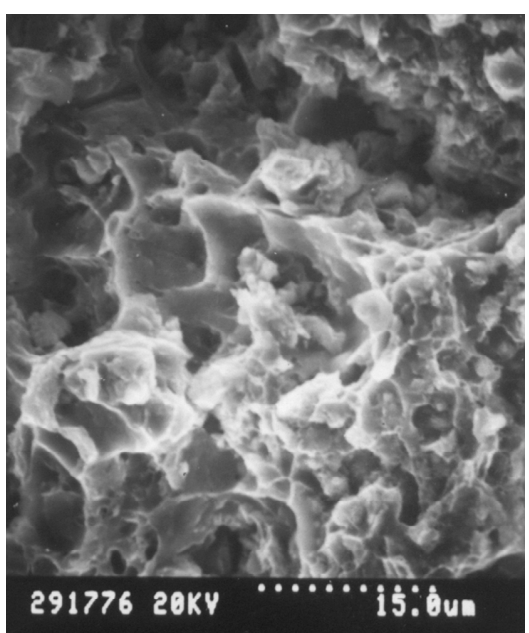

(c)

Figure 9. Fractographs of $\mathrm{SiC}_{\mathrm{p}} / 6061 \mathrm{Al}$ at various temperatures; (a) $620^{\circ} \mathrm{C}$; (b) $623^{\circ} \mathrm{C}$; (c) $625^{\circ} \mathrm{C}$.

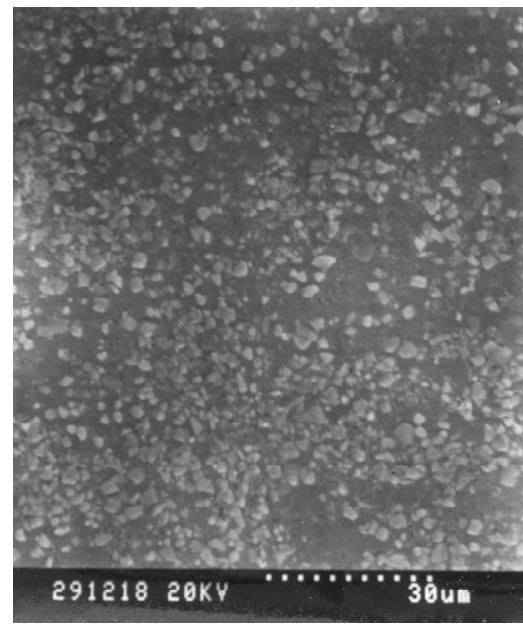

(a)

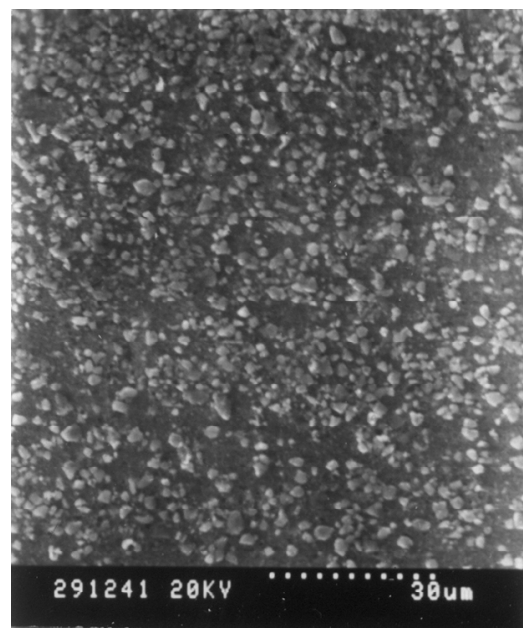

(b)

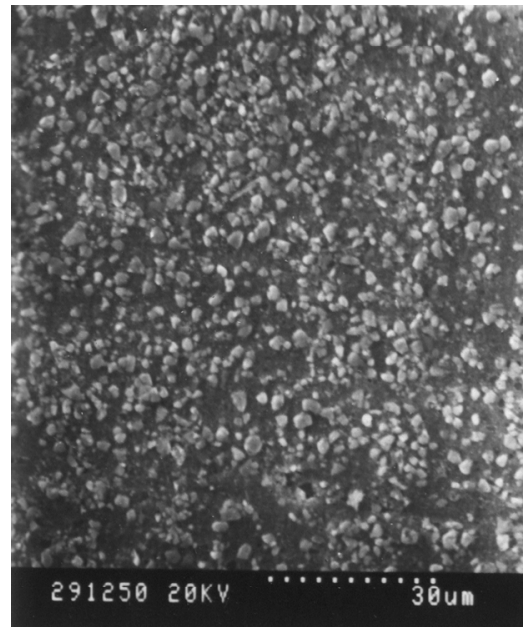

(c)

Figure 10. SEM micrographs of $\mathrm{Al}_{2} \mathrm{O}_{3 \mathrm{p}} / 6061 \mathrm{Al}$ welded joints at various welding temperatures; (a) $641^{\circ} \mathrm{C}$; (b) $644^{\circ} \mathrm{C}$; (c) $647^{\circ} \mathrm{C}$. 


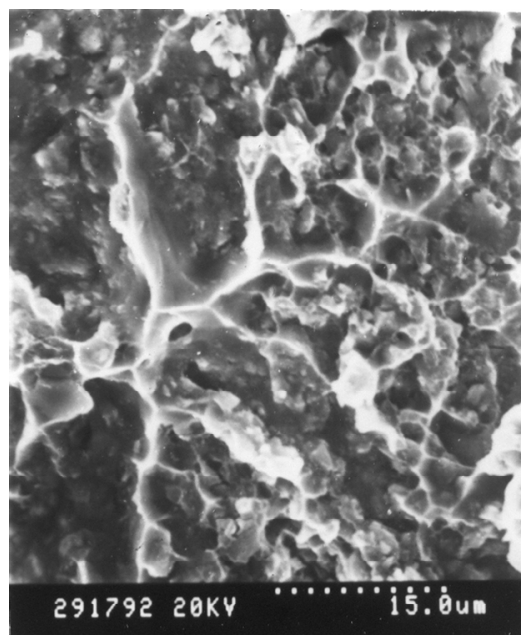

(a)

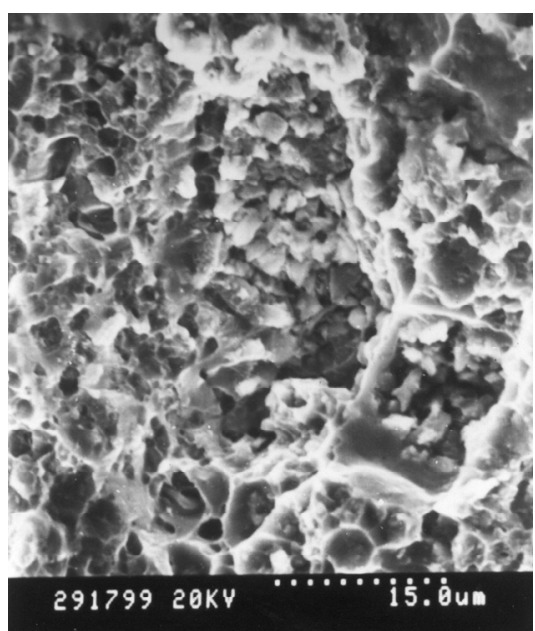

(b)

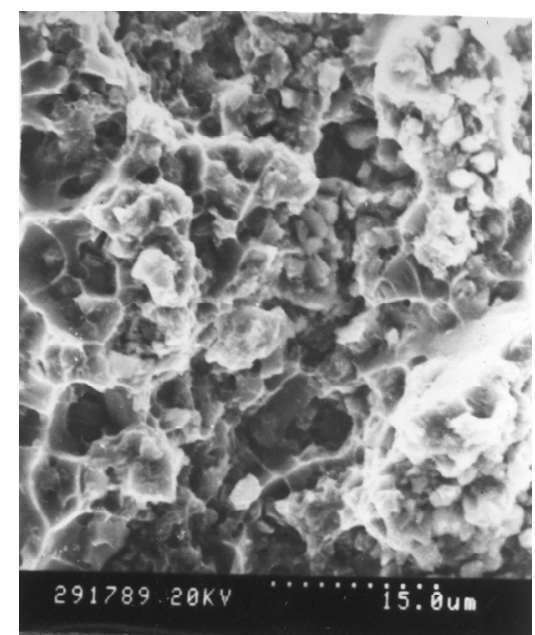

(c)

Figure 11. Fractographs of $\mathrm{Al}_{2} \mathrm{O}_{3 \mathrm{p}} / 6061 \mathrm{Al}$ at various temperatures; (a) $641^{\circ} \mathrm{C}$; (b) $644^{\circ} \mathrm{C}$; (c) $647^{\circ} \mathrm{C}$.

alloy to wet the reinforcement particles, and the diffusion capability of the atoms within the matrix was relatively low. Therefore, the indistinct welding interface between two specimens could be observed resulted in low tensile strength (about $240 \mathrm{MPa}$ for $\mathrm{SiC}_{\mathrm{p}} / 6061 \mathrm{Al}$ and $270 \mathrm{MPa}$ for $\mathrm{Al}_{2} \mathrm{O}_{3 \mathrm{p}} / 6061 \mathrm{Al}$ ). When the temperature is higher $\left(623^{\circ} \mathrm{C}\right.$ for $\mathrm{SiC}_{\mathrm{p}} / 6061 \mathrm{Al}$ and $644^{\circ} \mathrm{C}$ for $\left.\mathrm{Al}_{2} \mathrm{O}_{3 \mathrm{p}} / 6061 \mathrm{Al}\right)$, the liquid phase matrix alloy was formed enough to wet the reinforcement particles $(\mathrm{SiC})$, together with higher rate of the atom diffusion in the joint region (Figures 8(b) and 10(b)). Consequently, the joints could be welded successfully with the average strength of $260 \mathrm{MPa}$ for $\mathrm{SiC}_{\mathrm{p}} / 6061 \mathrm{Al}$ (about $72.2 \%$ of the $360 \mathrm{MPa}$ for the strength of parent aluminum matrix composite) and 282 $\mathrm{MPa}$ for $\mathrm{Al}_{2} \mathrm{O}_{3 \mathrm{p}} / 6061 \mathrm{Al}$ (about $70.5 \%$ of the $400 \mathrm{MPa}$ for the strength of parent aluminum matrix composite). As welding temperature increasing further (such as $625^{\circ} \mathrm{C}$ for $\mathrm{SiC}_{\mathrm{p}} / 6061 \mathrm{Al}$ and $647^{\circ} \mathrm{C}$ for $\mathrm{Al}_{2} \mathrm{O}_{3 \mathrm{p}} / 6061 \mathrm{Al}$ ), more and more liquid phase matrix alloy would be distributed in the welded interface, at the same time, more liquid phase matrix alloy reduced the effect of impact on the interface of the welded joints, subsequently prompted for the descending of the joint strength (Figures 8(c) and 10(c)).

Moreover, according to the fractures of welded joints at various temperatures shown in Figures 9 and 11, it showed that it agreed with Figures $\mathbf{8}$ and $\mathbf{1 0}$ very well, and the fractures were all dimple fractures with some reinforcement particles $\left(\mathrm{SiC}, \mathrm{Al}_{2} \mathrm{O}_{3}\right)$ in the dimple. Also, the results of $\mathrm{SiC}_{\mathrm{p}} / 6061 \mathrm{Al}$ were better than that of $\mathrm{Al}_{2} \mathrm{O}_{3 \mathrm{p}} / 6061 \mathrm{Al}$ due to a mild interfacial reaction between the reinforcement and matrix, which released the thermal mismatch stress to an acceptable extent between the reinforcement and matrix to allow load transfer from the matrix to reinforcement successfully. As a result, it had advantageous effect of improving the strength of welded joints further [18].

Based on microstructures of the welded joints with the optimal parameters (i.e., $T_{\mathrm{SiC}_{\mathrm{p}} / \mathrm{A} 356}=570^{\circ} \mathrm{C}, T_{\mathrm{SiC}_{\mathrm{p}} / 6061 \mathrm{Al}}$ $=623^{\circ} \mathrm{C}, T_{\mathrm{Al}_{2} \mathrm{O}_{3 \mathrm{p}}}=644^{\circ} \mathrm{C}, V_{I}^{\mathrm{p}}=560 \mathrm{~mm} / \mathrm{s}, t_{I}=10^{-2}-$ $\left.10^{-4} \mathrm{~s}, \delta=1 \mathrm{~mm}, t=30 \mathrm{~s}, P_{0}=5 \mathrm{MPa}\right)$ and its corresponding fracture surfaces as shown in Figures 5, 6, 8-11, the welded joint displayed with uniformly distributing reinforcement particles and microstructure almost similar to that of its parent composite (Figures 1-3). SEM of the fracture surface showed that the reinforcement particles had been perfectly wet and the composite structure of reinforcement/reinforcement had been changed to the state of reinforcement/matrix/reinforcement. XRD pattern of the fracture surfaces (Figure 12) did not illustrate the existence of any harmful phase or brittle phase of $\mathrm{Al}_{4} \mathrm{C}_{3}$. This suggested the effective interface transfers between reinforcement particles and matrix in the welded joint that subsequently provided favorable welding strength [16-18].

\subsection{Distribution of Dislocation in the Welded Joint}

The distribution of dislocation in the matrix neighboring to the interface of the welded joint by LPPIDW in comparison with its parent composite was shown in Figure. 13. The clearly distinctive interface between reinforcement particle and matrix indicated that the integration between the reinforcement particle and matrix was prominent. The effect of pulse-impact subsequently led to dislocation in the matrix lattices and showed sign of mutually entwisting to give higher welded strength. Comparatively, its dislocation distribution in the matrix neighboring to the interface was relatively denser than that in its parent composite (cf. Figures 13(a) and (b)). 


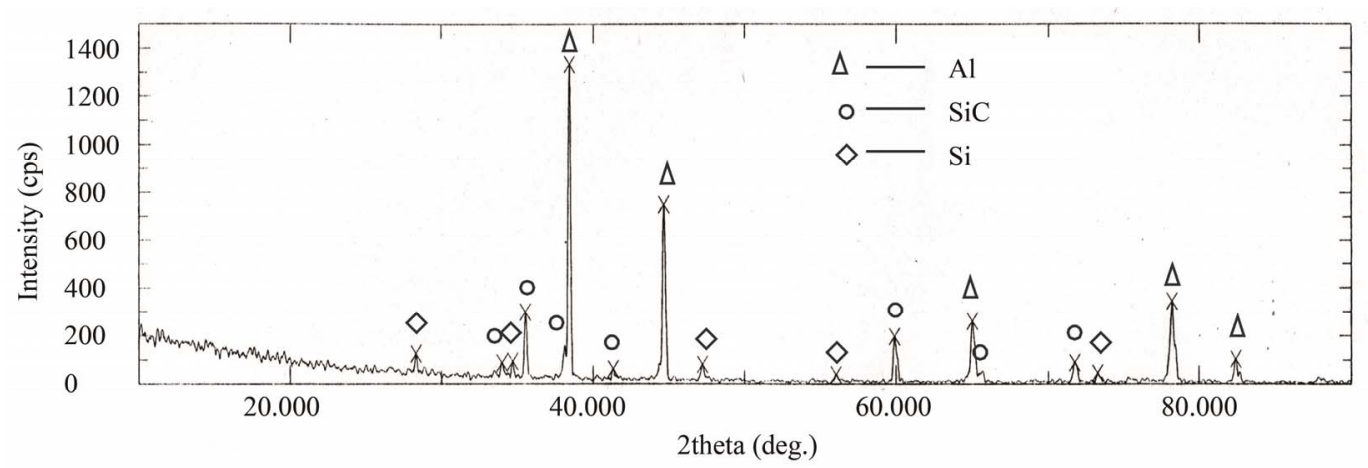

(a)

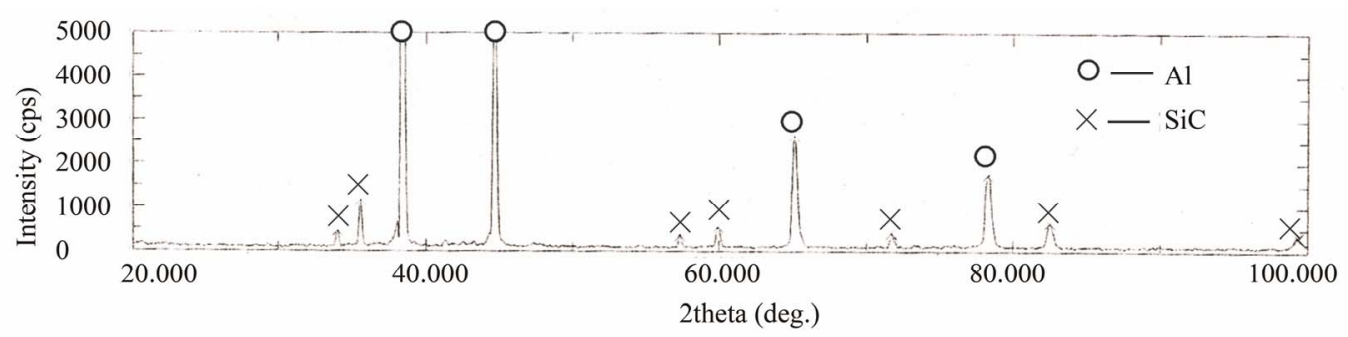

(b)

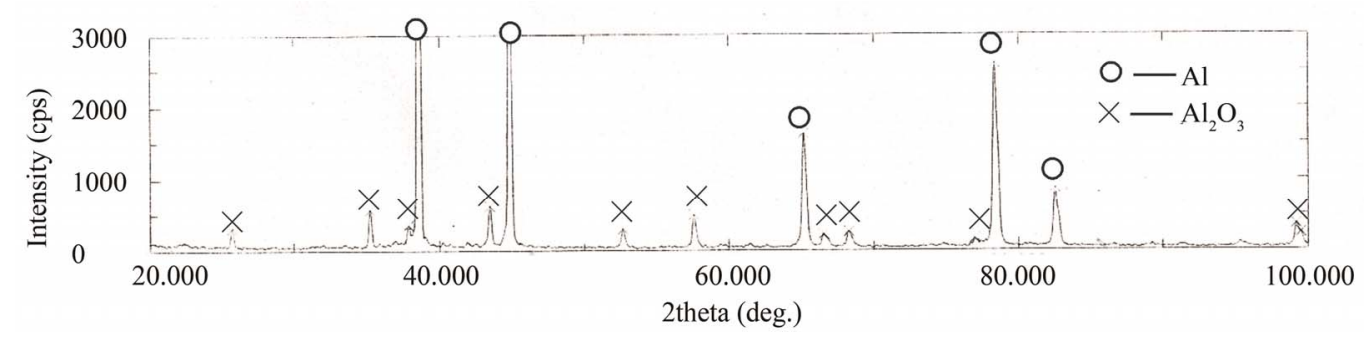

(c)

Figure 12. XRD pattern of the fracture surfaces; (a) $\mathrm{SiC}_{\mathrm{p}} / \mathrm{A356}$; (b) $\mathrm{SiC}_{\mathrm{p}} / 6061 \mathrm{Al}$; (c) $\mathrm{Al}_{2} \mathrm{O}_{3 \mathrm{p}} / 6061 \mathrm{Al}$.

Similarly, the density of dislocation and dislocation entwisting in the matrix away from the welded interface was also higher than that of its parent composite (cf. Figures 14(a) and (b)). Such favorable characteristics ultimately gave relatively superior strength of the welded joint to that of conventional diffusion welding [16-18].

\subsection{Formation of Nano-Grains in the Weld}

SEM micrograph (Figure 15) of a weld by LPPIDW displayed some newly-formed nano-grains in the lattices of the joint. These nano-grains would seat in the interstices of crystal lattices and create new grain boundary in hindering the movement of neighbouring grains and subsequently improved obviously the properties of the welded joints. The formation of new nano-grains was the advantageous effect of pulse-impact in LPPIDW. In addition, XRD pattern of the fracture surface (Figure 12) did not illustrate the existence of any harmful phase or brittle phase of $\mathrm{Al}_{4} \mathrm{C}_{3}$. This suggested the effective interface transfers between reinforcement particles and matrix in the welded joint that subsequently provided favorable welding strength [16-18].

\section{Conclusions}

Results of this study on the microstructures of welded joints of particle reinforcement aluminum matrix composites $\left(\mathrm{SiC}_{\mathrm{p}} / \mathrm{A} 356, \mathrm{SiC}_{\mathrm{p}} / 6061 \mathrm{Al}, \mathrm{Al}_{2} \mathrm{O}_{3 \mathrm{p}} / 6061 \mathrm{Al}\right)$ using liquid-phase-pulse-impact diffusion welding process show that:

1) Pulse-impact in liquid-phase-pulse-impact diffusion welding in joining particle reinforcement aluminum matrix composites $\left(\mathrm{SiC}_{\mathrm{p}} / \mathrm{A} 356, \mathrm{SiC}_{\mathrm{p}} / 6061 \mathrm{Al}, \mathrm{Al}_{2} \mathrm{O}_{3 \mathrm{p}} / 6061 \mathrm{Al}\right)$ resulted in higher density of dislocation in the matrix neighboring to and away from the interface than their parent composite. Simultaneously, the dislocation entwisted mutually and intensively in the welded joint propitious to improve the strength of welded joints.

2) There was distinctly clear interface between reinforcement particle and matrix. It overcame some diffusion problems normally encountered in conventional diffusion 


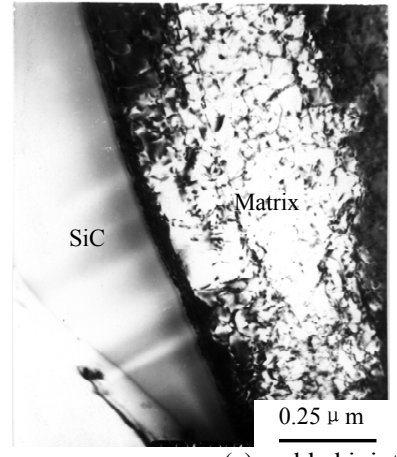

(a) welded joint

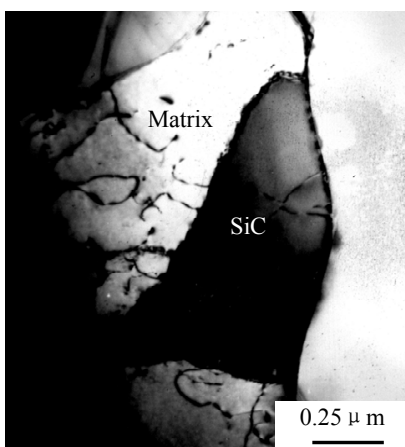

(b) parent composite

(A)

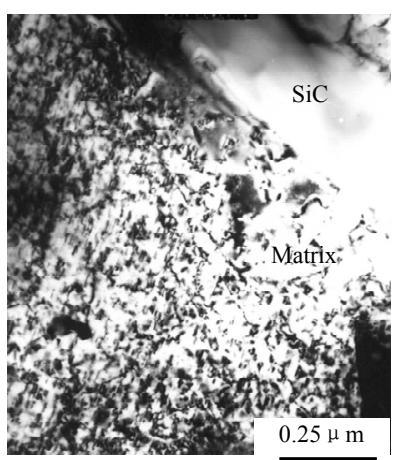

(a) welded joint

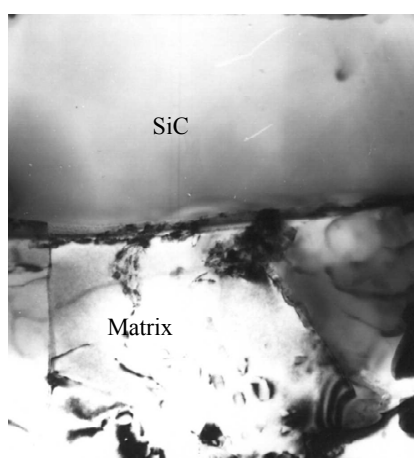

(b) parent composite

(B)

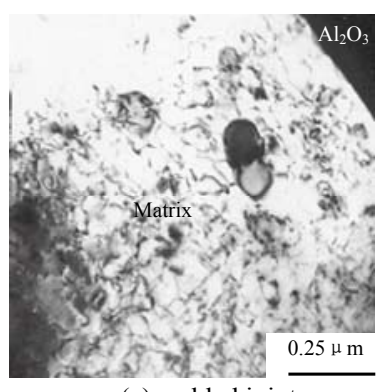

(a) welded joint

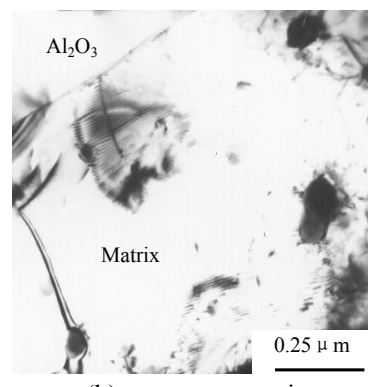

(b) parent composite

(C)

Figure 13. Distribution of dislocation in the matrix neighboring to the interface of the welded joint and parent composite respectively; (A) $\mathrm{SiC}_{\mathrm{p}} / \mathrm{A356}$; (B) $\mathrm{SiC}_{\mathrm{p}} / 6061 \mathrm{Al}$; (C) $\mathrm{Al}_{2} \mathrm{O}_{3 \mathrm{p}} / 6061 \mathrm{Al}$.

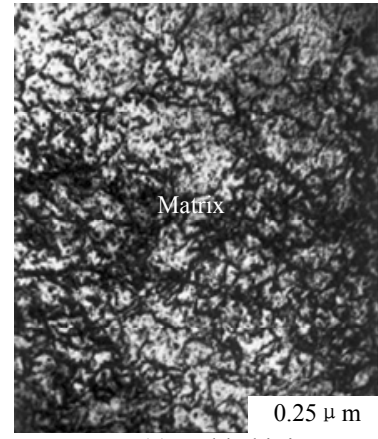

(a) welded joint

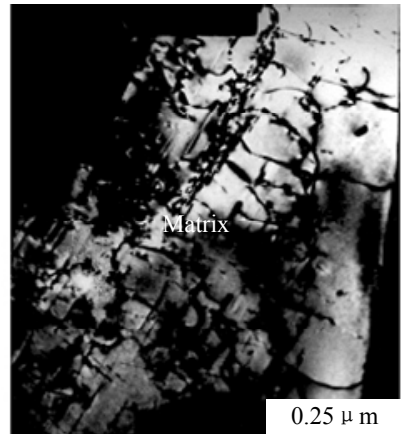

(b) parent composite

(A)

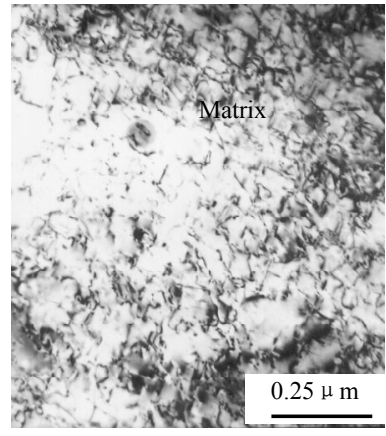

(a) welded joint

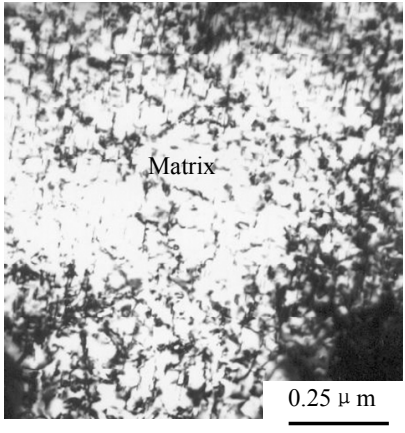

(a) welded joint

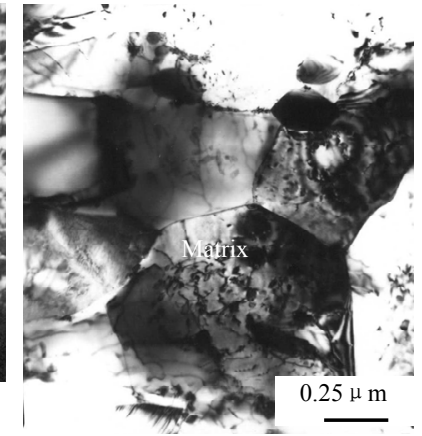

(b) parent composite

(B)

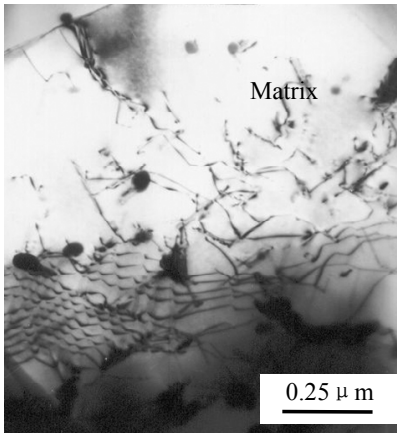

(b) parent composite

(C)

Figure 14. Distribution of dislocation in the matrix away from the interface of the welded joint and parent composite respectively; (A) $\mathrm{SiC}_{\mathrm{p}} / \mathrm{A356}$; (B) $\mathrm{SiC}_{\mathrm{p}} / 6061 \mathrm{Al}$; (C) $\mathrm{Al}_{2} \mathrm{O}_{3 \mathrm{p}} / 6061 \mathrm{Al}$. 


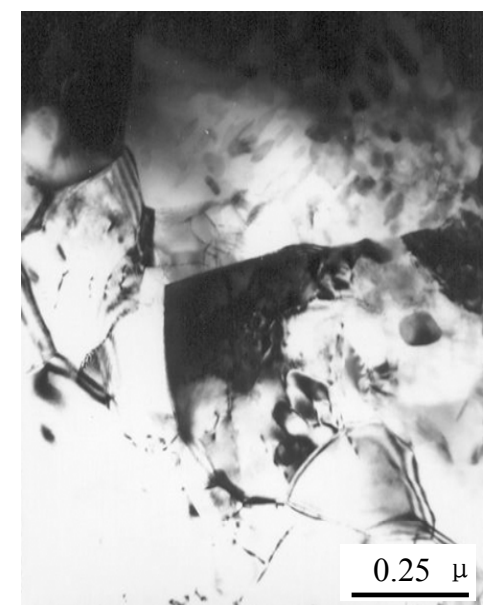

(a)

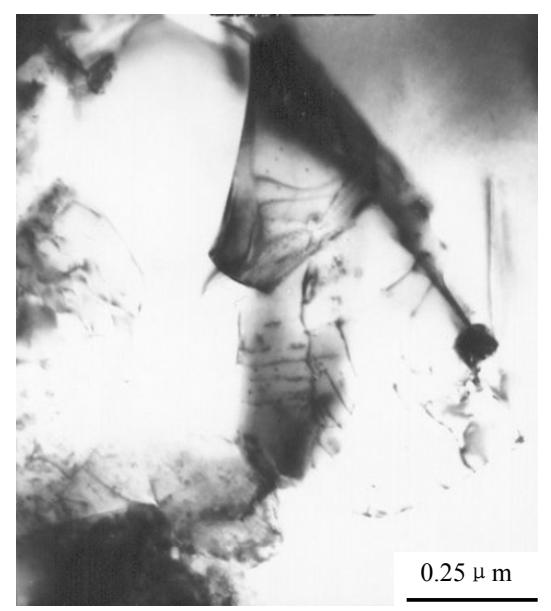

(b)

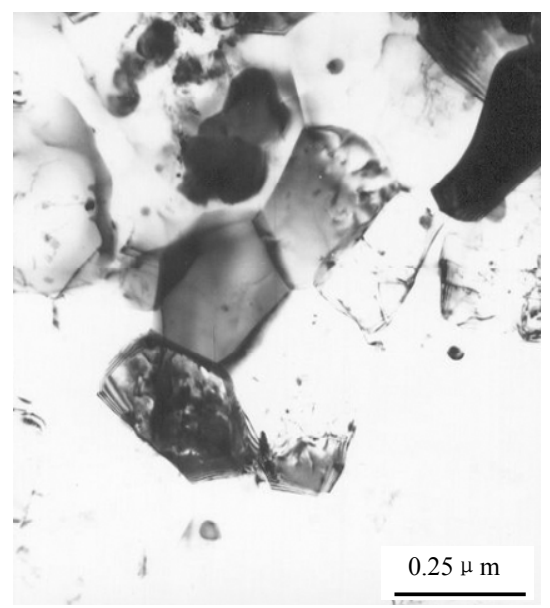

(c)

Figure 15. Nano-grains formed in the weld of particle reinforcement aluminum matrix composites during the LPPIDW; (a) $\mathrm{SiC}_{\mathrm{p}} / \mathrm{A} 356$; (b) $\mathrm{SiC}_{\mathrm{p}} / 6061 \mathrm{Al}$; (c) $\mathrm{Al}_{2} \mathrm{O}_{3 \mathrm{p}} / 6061 \mathrm{Al}$.

welding, and prevented the formation of harmful microstructure or brittle phase in the welded joint.

3) The joint by LPPIDW process would form nanograins. The newly-formed nano-grains would improve the properties of welded joints resulted in higher tensile strength.

\section{Acknowledgements}

This work is supported by City University of Hong Kong Strategic Research Grant (SRG) No. 7002582.

\section{REFERENCES}

[1] S. V. Nair, J. K. Tien and R. C. Bates, "SiC-Reinforced Aluminium Metal Matrix Composites," International Metals Reviews, Vol. 30, No. 6, 1995, pp. 275-288.

[2] A. Pirondi and L. Collini, "Analysis of Crack Propagation Resistance of $\mathrm{Al}-\mathrm{Al}_{2} \mathrm{O}_{3}$ Particulate-Reinforced Composite Friction Stir Welded Butt Joints," International Journal of Fatigue, Vol. 31, No. 1, 2009, pp. 111-121. doi:10.1016/j.ijfatigue.2008.05.003

[3] F. Rotundo, L. Ceschini, A. Morri, T. S. Jun and A. M. Korsunsky, "Mechanical and Microstructural Characterization of $2124 \mathrm{Al} / 25 \mathrm{vol} \% \mathrm{SiC}_{\mathrm{p}}$ Joints Obtained by Linear Friction Welding (LFW)," Composite Part A: Applied Science and Manufacturing, Vol. 41, No. 9, 2010, pp. 1028-1037. doi:10.1016/j.compositesa.2010.03.009

[4] J. M. G. de Salazar and M. I. Barrena, "Dissimilar Fusion Welding of AA7020/MMC Reinforced with $\mathrm{Al}_{2} \mathrm{O}_{3}$ Particles. Microstructure and Mechanical Properties," Materials Science and Engineering A, Vol. 352, 2003, pp. 162168.

[5] D. J. Loyd, "Particle Reinforced Aluminum Magnesium Composites," International Materials Reviews, Vol. 39, No. 1, 1994, pp. 1-22. doi:10.1179/095066094790150982

[6] J. Maity, T. K. Pal and R. Maiti, “Transient Liquid Phase Diffusion Bonding of 6061-15 wt\% SiCp in Argon Envi- ronment," Journal of Materials Processing Technology, Vol. 209, No. 7, 2009, pp. 3568-3580.

doi:10.1016/j.jmatprotec.2008.08.015

[7] J. S. U. Schell, J. Guilleminot, C. Binetruy and P. Krawczak, "Computational and Experimental Analysis of Fusion Bonding in Thermoplastic Composites: Influence of Process Parameters," Journal of Materials Processing Technology, Vol. 209, No. 11, 2009, pp. 5211-5219. doi:10.1016/j.jmatprotec.2009.03.008

[8] N. S. Sundaram and N. Murugan, "Tensile Behavior of Dissimilar Friction Stir Welded Joints of Aluminum Alloys," Materials \& Design, Vol. 31, No. 9, 2010, pp. 4184-4193. doi:10.1016/j.matdes.2010.04.035

[9] H. Arik, M. Aydin, A. Kurt and M. Turker, "Weldability of $\mathrm{Al}_{4} \mathrm{C}_{3}$-Al Composites via Diffusion Welding Technique," Materials \& Design, Vol. 26, No. 6, 2005, pp. 555-560. doi:10.1016/j.matdes.2004.07.017

[10] American Welding Society, "Welding Handbook," American Welding Society, Miami, 1996.

[11] A. H. Feng, B. L. Xiao and Z. Y. Ma, "Effect of Microstructural Evolution on Mechanical Properties of Friction Stir Welded AA2009/SiC $\mathrm{P}_{\mathrm{p}}$ Composite," Composites Science and Technology, Vol. 68, No. 9, 2008, pp. 21412148. doi:10.1016/j.compscitech.2008.03.010

[12] J. A. Wert, "Microstructures of Friction Stir Weld Joints between an Aluminium-Base Metal Matrix Composite and a Monolithic Aluminium Alloy," Scripta Materialia, Vol. 49, No. 6, 2003, pp. 607-612. doi:10.1016/S1359-6462(03)00215-X

[13] G. J. Fernandez and L. E. Murr, "Characterization of Tool Wear and Weld Optimization in the Friction-Stir Welding of Cast Aluminum $359+20 \%$ SiC Metal-Matrix Composite," Materials Characterization, Vol. 52, No. 1, 2004, pp. 65-75. doi:10.1016/j.matchar.2004.03.004

[14] C. J. Hsu, P. W. Kao and N. J. Ho, "Ultrafine-Grained $\mathrm{Al}-\mathrm{Al}_{2} \mathrm{Cu}$ Composite Produced In-Situ by Friction Stir Processing," Scripta Materialia, Vol. 53, No. 3, 2005, pp. 341-345. doi:10.1016/j.scriptamat.2005.04.006 
[15] L. M. Marzoli, A. V. Strombeck, J. F. Dos Santos, C. Gambaro and L. M. Volpone, "Friction Stir Welding of an AA6061 $/ \mathrm{Al}_{2} \mathrm{O}_{3} / 20 \mathrm{p}$ Reinforced Alloy," Composites Science and Technology, Vol. 66, No. 2, 2006, pp. 363371. doi:10.1016/j.compscitech.2005.04.048

[16] W. Guo, M. Hua and J. K. L. Ho, "Study on LiquidPhase-Impact Diffusion Welding $\mathrm{SiC}_{\mathrm{p}} / \mathrm{ZL101}$," Composites Science and Technology, Vol. 67, No. 6, 2007, pp. 1041-1046. doi:10.1016/j.compscitech.2006.06.006

[17] W. Guo, M. Hua, J. K. L. Ho and H. W. Law, "Mecha- nism and Influence of Pulse-Impact on Properties of Liquid Phase Pulse-Impact Diffusion Welded SiCp/A356," The International Journal of Advanced Manufacturing Technology, Vol. 40, No. 9-10, 2008, pp. 898-906. doi:10.1007/s00170-008-1411-y

[18] W. Guo, M. Hua, H. W. Law and J. K. Lim Ho, "Liquid Phase Impact Diffusion Welding of $\mathrm{SiC}_{\mathrm{p}} / 6061 \mathrm{Al}$ and Its Mechanism," Materials Science and Engineering A, Vol. 490, No. 1-2, 2008, pp. 427-437. doi:10.1016/j.msea.2008.01.058 